\title{
Integrated petrophysical study to validate water saturation from well logs in Bahariya Shaley Sand Reservoirs, case study from Abu Gharadig Basin, Egypt
}

\author{
Mohamed El-Bagoury ${ }^{1}$
}

Received: 19 April 2020 / Accepted: 30 July 2020 / Published online: 18 August 2020

(c) The Author(s) 2020

\begin{abstract}
Water saturation is a key parameter in evaluating oil and gas reservoirs and calculating OIIP and GIIP for petroleum fields. The late Cretaceous Bahariya reservoir contains variable amounts of clay minerals. Bore hole logs are affected with those clay minerals particularly the density and resistivity logs. Several methods are acknowledged to determine the true water saturation from well logs in shaley sand reservoirs. Each method assumes a sort of corrections to amount of shale distributed in the reservoir. The scope of this petrophysical study is to integrate core analysis and bore hole logs to investigate the characteristics of water saturation in the Bahariya reservoirs. Comparison between most of the significant shaley sand methods is presented in this research. Reservoir lithology and mineralogy are explained by Elan-model while bore hole images are used for fine-tuning the electrofacies. Siltstone, shaley sand and clean sandstones are the main electrofacies that is characterizing the Bahariya reservoir rocks. For accurate saturation results, some core samples have been used for validating the log-derived water saturation. Dean stark and cation exchange capacity experiments are integrated with bore hole logs to calculate the error in water saturation for each method for best calibration. The successful integration between logs and core measurements led to convenient log evaluation and accurate understanding for the Bahariya reservoir in the prospective part of Abu Gharadig basin.
\end{abstract}

Keywords Water saturation $\cdot$ Bahariya $\cdot$ Well logs $\cdot$ Electrofacies $\cdot$ Mineralogy $\cdot$ CEC

\begin{tabular}{|c|c|c|c|}
\hline \multicolumn{2}{|c|}{ Abbreviations } & $m$ & Cementation factor (unitless) \\
\hline$a$ & Constant multiplier (unitless) & $m^{*}$ & Modified cementation factor(non-Archie) \\
\hline \multirow[t]{2}{*}{$B$} & Equivalent cationic conductance of a sodium ion & & (unitless) \\
\hline & $(\mathrm{L} \mathrm{S} / \mathrm{m})$ & $n$ & Saturation exponent (unitless) \\
\hline \multirow{3}{*}{$\begin{array}{l}\text { BHI } \\
\text { BVH }\end{array}$} & Bore hole image & $n^{*}$ & Modified saturation exponent (non-Archie) \\
\hline & Bulk volume of hydrocarbon (hydrocarbon pore & & (unitless) \\
\hline & volume) (fraction) & $Q_{\mathrm{v}}$ & Cation exchange capacity volumetric (Unite per \\
\hline \multirow[t]{2}{*}{ BVW } & Bulk volume of water (water pore volume) & & liter) \\
\hline & (fraction) & $R_{\mathrm{t}}$ & True (deep) resistivity in the un-invaded zone \\
\hline $\mathrm{CEC}$ & Cation exchange capacity measured in lap (S/m) & & $(\mathrm{Ohm}-\mathrm{m})$ \\
\hline \multirow[t]{2}{*}{$\mathrm{CEC}^{*}$} & Cation exchange capacity calculated from logs & $R_{\mathrm{s}}$ & Shallow resistivity in the invaded zone (Ohm-m) \\
\hline & $(\mathrm{S} / \mathrm{m})$ & $R_{\mathrm{sh}}$ & Resistivity of shale (Ohm-m) \\
\hline$F$ & Formation factor (unitless) & $S_{\mathrm{w}}$ & Un-invaded zone water saturation (\%) \\
\hline $\mathrm{Gr}_{\min }$ & Gamma ray minimum (API) & $S_{\mathrm{h}}$ & Un-invaded zone hydrocarbon saturation (\%) \\
\hline $\mathrm{Gr}_{\max }$ & Gamma ray maximum (API) & $R_{\mathrm{w}}$ & Formation water resistivity (Ohm-m) \\
\hline \multirow[t]{3}{*}{$\mathrm{LR}_{\mathrm{p}}$} & Low resistivity pay & $R_{\mathrm{v}}$ & Vertical resistivity (Ohm-m) \\
\hline & & $R_{\mathrm{h}}$ & Horizontal resistivity (Ohm-m) \\
\hline & & $V_{\mathrm{sh}}$ & Volume of shale (fraction) \\
\hline & imed El-Bagoury & $\varnothing_{\mathrm{e}}$ & Effective porosity (fraction) \\
\hline & Bagoury@Bapetco.net & $\varrho_{\mathrm{b}}$ & Bulk density $\left(\mathrm{g} / \mathrm{cm}^{3}\right)$ \\
\hline \multirow{2}{*}{$\begin{array}{l}\mathrm{P} \\
\mathrm{C}\end{array}$} & Eum Engineering Department, Badr El-Din Petroleum & $\varrho_{\mathrm{ma}}$ & Matrix density $\left(\mathrm{g} / \mathrm{cm}^{3}\right)$ \\
\hline & any, Cairo, Egypt & $\varrho_{\mathrm{f}}$ & Fluid density $\left(\mathrm{g} / \mathrm{cm}^{3}\right)$ \\
\hline
\end{tabular}


$\Delta T_{\text {ma }} \quad$ Matrix transit time $(\mu \mathrm{s} / \mathrm{ft})$

$\Delta T_{\mathrm{f}} \quad$ Fluid transit time $(\mu \mathrm{s} / \mathrm{ft})$

\section{Introduction}

Petrophysical parameters as volume of shale $\left(V_{\mathrm{sh}}\right)$, porosity $(\varnothing)$ and water saturation $\left(S_{\mathrm{w}}\right)$ are generally used to evaluate the potential of hydrocarbon-bearing formations. In clean formations, water saturation can be calculated using the simple conductivity model of Archie's equation, while in shaley sand reservoirs the clay minerals are bringing extra conductivity, which may bias the computed water saturation.

Shaley sand models were presented in North America during the Fifties by Hill and Milburn's (1955) and their work led to cation exchange capacity concept by Waxman and Smits (1968). The problem of identifying low resistivity pay through wire line logs has been acknowledged with much early focus on Texas and Louisiana gulf coast (Tixier et al. 1968; Murphy and Owens 1972). Several models discussed the true water saturation in shaley sands as Simandoux (1963) and modified Simandoux equation by Bardon and Pied (1969), Indonesia and modified Indonesia formula by Poupon and Leveaux (1971), Juhasz (1981), Bassiouni (1994) and Iheanacho (2014). This present work aims to discuss different methods in calculating water saturation from bore hole logs which will be compared to values measured from core samples.

Bahariya formation is one of the shaley sand reservoirs that contain variable amounts of clay minerals (Abu Shady et al. 2010); those clay minerals which affect the pore system challenged the simple water saturation approaches (Shedid and Saad 2017). Bahariya mineralogy was investigated in Western Desert fields by many authors Hegazy and Labib (1996), Wehr et al. (2002), Abu Shady et al. (2010), El Sayed and El Sayed (2015), Shokry et al. (2015). The hydrocarbons potentiality of the late Cretaceous Bahariya Formation was proven in Abu Gharadig basin as $90 \%$ of Western Desert fields was producing from it (EGPC 1992).

Formation evaluation technique is connected to the amount and type of clays in pore system. The present work aims to discuss the clay minerals characterization using bore hole logs and extra conductivity known as cation exchange capacity (CEC) for one of the widely distributed reservoirs in Abu Gharadig basin and Western Desert (Fig. 1).

The study area is located in the easternmost part of Abu Gharadig basin some $150 \mathrm{~km}$ west of Cairo the capital of Egypt and about $100 \mathrm{~km}$ from Mediterranean Sea coast northeast of the inverted Mubarak Ridge (Fig. 1). The petrophysical data used in this work are obtained from the two oil fields Neag-1 and Neag-2, which were discovered at 2007/2008 by SHELL and currently operated by BAPETCO.
The Neag-1 field was investigated before by many authors (Bakr et al. 2010; ElBelisy et al. 2010; El-Bagoury et al. 2017; El-Bagoury 2019; El Sayed et al. 2019). Fit for purpose reservoir modeling for the geological uncertainties as., structure and stratigraphy was done for Bahariya reservoirs (Fault block compartmentalization, Fault sealing, sub-seismic faults, net reservoir, hydrocarbon saturation) by Bakr et al. (2010) to propose a fast track strategy for early field development. The key petrophysical parameters and its related uncertainties were adjusted by ElBelisy et al. (2010) via integrating the core photographs and bore hole logs to fine-tune the net reservoir cutoffs initially selected based on other analogues. This was mainly effective in approximating the in place volumes which enhanced after shaley sand trials. The number of segments and zones was increased by El-Bagoury et al. (2017) to achieve detailed modeling for Bahariya reservoir in order to match the production and pressure history of the field. This approach enhanced the geologic and engineering understanding of Neag-1 field for best water flood pattern selection in future field development.

The mercury injection capillary pressure (MICP) lap test was used by El Sayed et al. (2019) to characterize the pore throat radius and classify the hydraulic flow units of Bahariya reservoir into ten hydraulic flow units governed by lithology variations and flaser laminations as direct impact of sedimentation and diagenetic processes.

The cation exchange capacity (CEC) was not considered in the study area before as one of the shaley sand key methods. The recent water saturation analysis of dean stark is used in validating models of minimum saturation error. Furthermore, the Elan models were applied before in similar fields but not in the study area where this model is used to fine-tune the net pay reservoir and to identify the matrix and cement contents.

\section{Geologic setting}

Abu Gharadig basin is one of the Western Desert large-scale structural provinces, (Meshref 1990; EGPC 1992; Schlumberger 1995; Dolson et al. 2001). During the late Cretaceous, axis of the Abu Gharadig basin was mainly trending east-west occasionally associated with northeast trend, these trends control the deposition in the basin and the structural deformation was controlled by the E-W to ENE oriented faults (Bayoumi 1996) (Fig. 2). The basin consists of several ENE elongated pull apart grabens formed in the early Cretaceous and most of Abu Gharadig faults die out on the Apollonia formation (Abdel Aal and Moustafa 1988; Bakry 1994, 2005; Bayoumi 1996; Ibrahim 2014).

The study area is located between the Kattania and Mubarak highs affected by a series of extensive compression known as the "Syrian Arc" trending northeast-southwest (Moustafa 


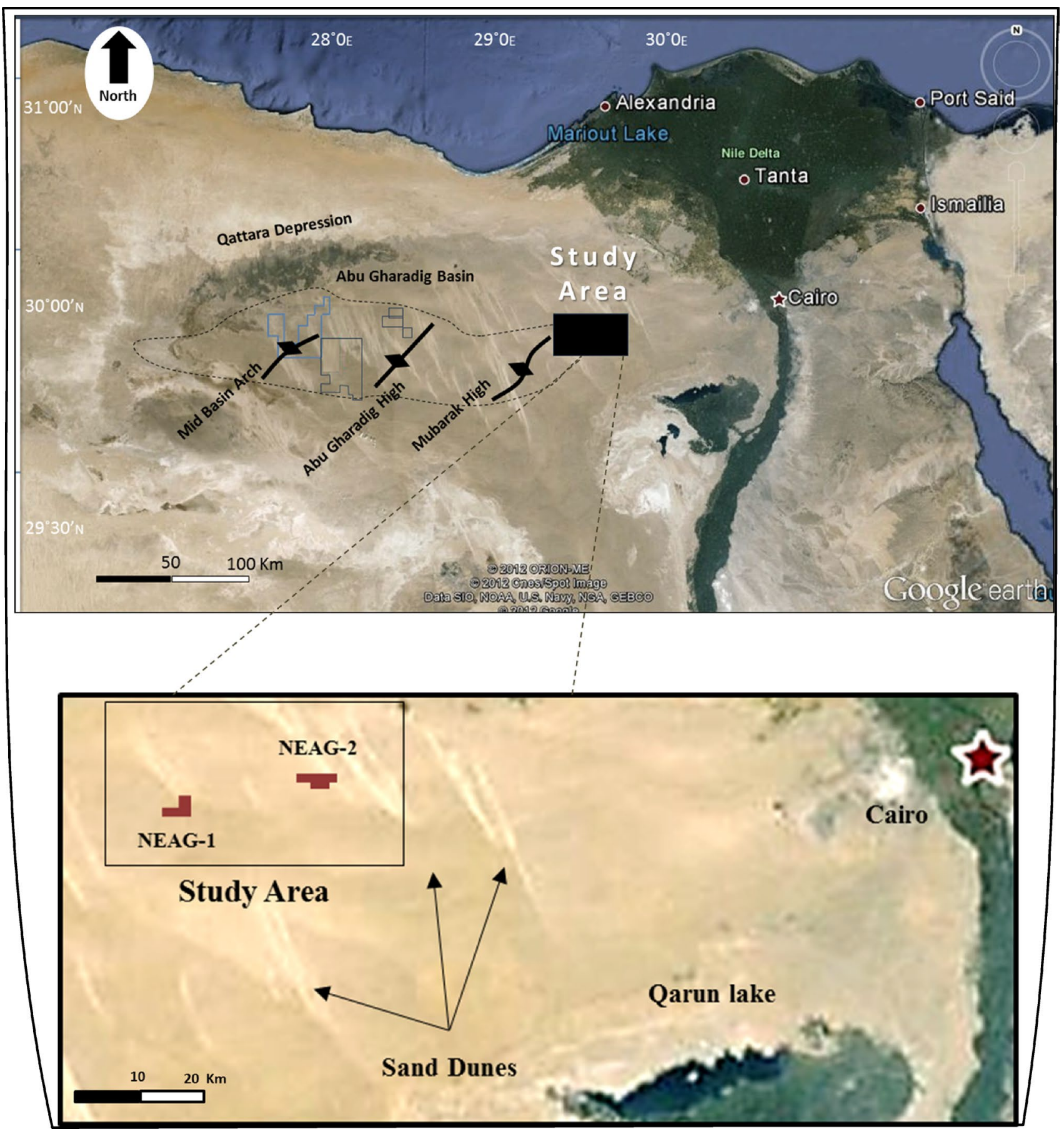

Fig. 1 Location map of the study area (Google Earth Maps 2012)

and Khalil 1990). The Bahariya Formation is a sedimentary sequence deposited in a shallow marine to near-shore environment at the beginning of the Late Cretaceous (Cenomanian) transgression in the Western Desert of Egypt (Said 1962, 1990; El Ayouty 1990; Wahdan et al. 1996). Barrier bars, stream mouth bars, point bars and distributary channels are the identified facies in the Bahariya Formation (El Sayed et al. 1993) encountered in the Salam and Khalda oil fields.
The Bahariya reservoir is subdivided into two unit's separated by laterally extended geo-markers (flooding shale or paleosoles). The middle and lower Bahariya reservoirs of late Cretaceous age are described as overall transgressive sequence with few stacking cycles (Mahsoub et al. 2012) (Fig. 3). The Lower/Middle Bahariya reservoirs are interpreted to be deposited in a shallow marine/ marginal marine depositional environment (Franks 1982; 


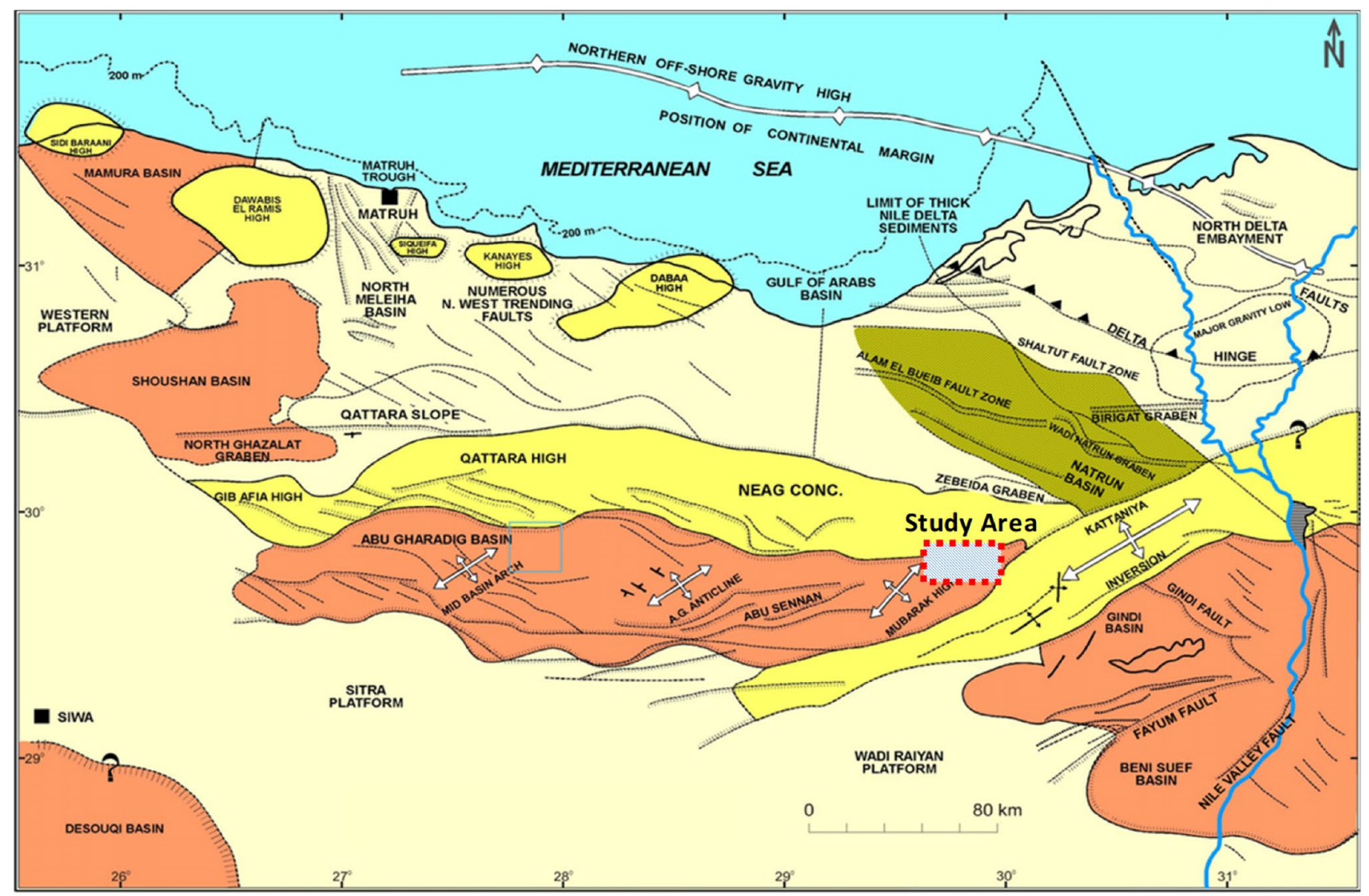

Fig. 2 Basic and major tectonic elements on Western Desert, Egypt (modified after Bayoumi 1996)

Catuneanu et al. 2006; Halisch et al. 2009; Bakr et al. 2010).

\section{Data and methods}

The present work is discussing shaley sand impact on water saturation for the hydrocarbon-bearing reservoirs in Neag-1 and Neag-2 oil fields. Bore hole logs are used to determine the petrophysical properties of the Bahariya shaley sand reservoirs using the Techlog software (Table 1). Core analysis is also used to calibrate the petrophysical parameters as porosity $(\varnothing)$ and water saturation $\left(S_{\mathrm{w}}\right)$ which calculated from logs (Table 2). The water saturation is measured in laboratory using the distillation method of Dean and Stark (1920) and according to API recommended practice 1998. The distillation method is a direct method for measuring water saturation from a core plug, while the cation exchange capacity (CEC) is the indirect method utilized to calculate the shale effect on electrical resistivity. CEC is defined as the excess conductivity caused by the clay minerals. CEC is measured in lap to fully brine saturated plugs of variable salinities as per Waxman and Smits (1968), Juhasz (1981) and Crain's Petrophysical Handbook (2000).

The calculated $S_{\mathrm{w}}$ from Archie model is reaching $80 \%$ in some intervals, while the initial production data for these intervals indicated $0 \%$ water production. These production data challenged the saturation by Archie model for the Bahariya reservoir (El-Bagoury 2015, 2019).

\section{Well log analysis}

The objective of this process is to evaluate the Bahariya reservoirs using recorded bore hole logs to detect the net hydrocarbon-bearing zones and calculate the different petrophysical parameters (such as $V_{\mathrm{sh}}, \varnothing_{\mathrm{e}}$ and $S_{\mathrm{w}}$ ). The presence of clay minerals is affecting the gamma ray and resistivity tool response, which may bias the definition of the true formation saturation only from bore hole logs. The formation evaluation workflow used in this study is schematically shown in Fig. 4.

Shale volume is calculated by gamma ray method using linear relationship (Schlumberger 1972, 1989). Porosity is calculated from porosity logs, density logs, neutron logs and sonic logs using Wyllie Equation 1950. Porosity from 


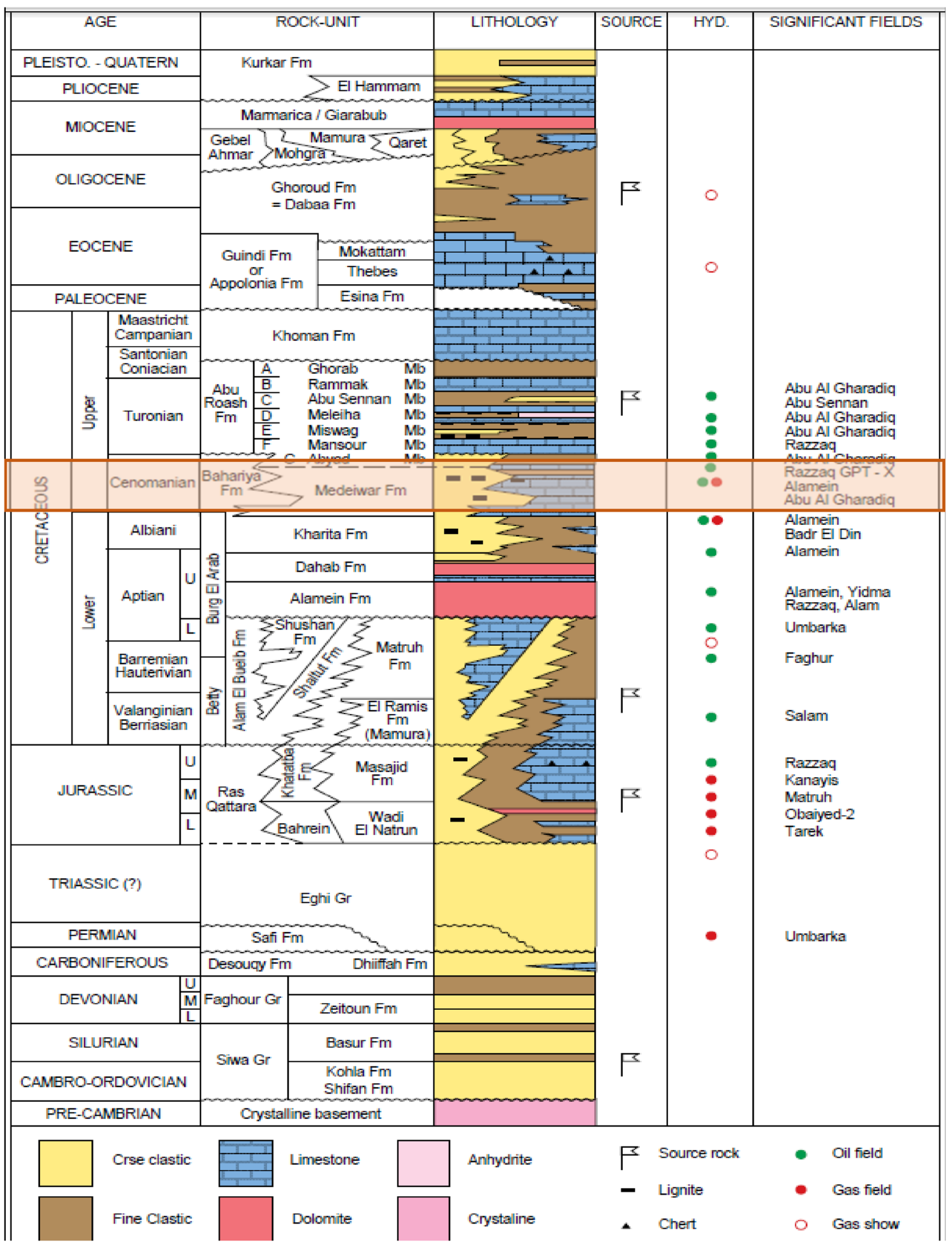

Fig. 3 North Western Desert Stratigraphic column (WEC 1995 by Schlumberger) 
Table 1 Summary of available well log data

\begin{tabular}{lll}
\hline Bore hole logs & Neag-1 & Neag-2 \\
\hline Gamma ray & $\sqrt{ }$ & $\sqrt{ }$ \\
Spectral.GR & $\sqrt{ }$ & X \\
Photoelectric factor & $\sqrt{ }$ & $\sqrt{ }$ \\
Shallow resistivity $\left(R_{\mathrm{s}}\right)$ & $\sqrt{ }$ & $\sqrt{ }$ \\
Deep resistivity $\left(R_{\mathrm{t}}\right)$ & $\sqrt{ }$ & $\sqrt{ }$ \\
Neutron $(\varnothing)$ & $\sqrt{ }$ & $\sqrt{ }$ \\
Density $\left(\varrho_{\mathrm{b}}\right)$ & $\sqrt{ }$ & $\sqrt{ }$ \\
Bore hole image_(BHI) & $\sqrt{ }$ & $\sqrt{ }$ \\
Compressional sonic $\left(V_{\mathrm{p}}\right)$ & $\sqrt{ }$ & $\mathrm{X}$ \\
\hline
\end{tabular}

Table 2 Summary of available core analysis data

\begin{tabular}{lcll}
\hline Analysis & $\begin{array}{l}\text { Number of } \\
\text { plugs }\end{array}$ & Neag-1 & Neag-2 \\
\hline Cation exchange capacity, CEC & 10 & $\sqrt{ }$ & $\mathrm{X}$ \\
Water saturation, Dean Stark & 5 & $\mathrm{X}$ & $\sqrt{ }$ \\
\hline
\end{tabular}

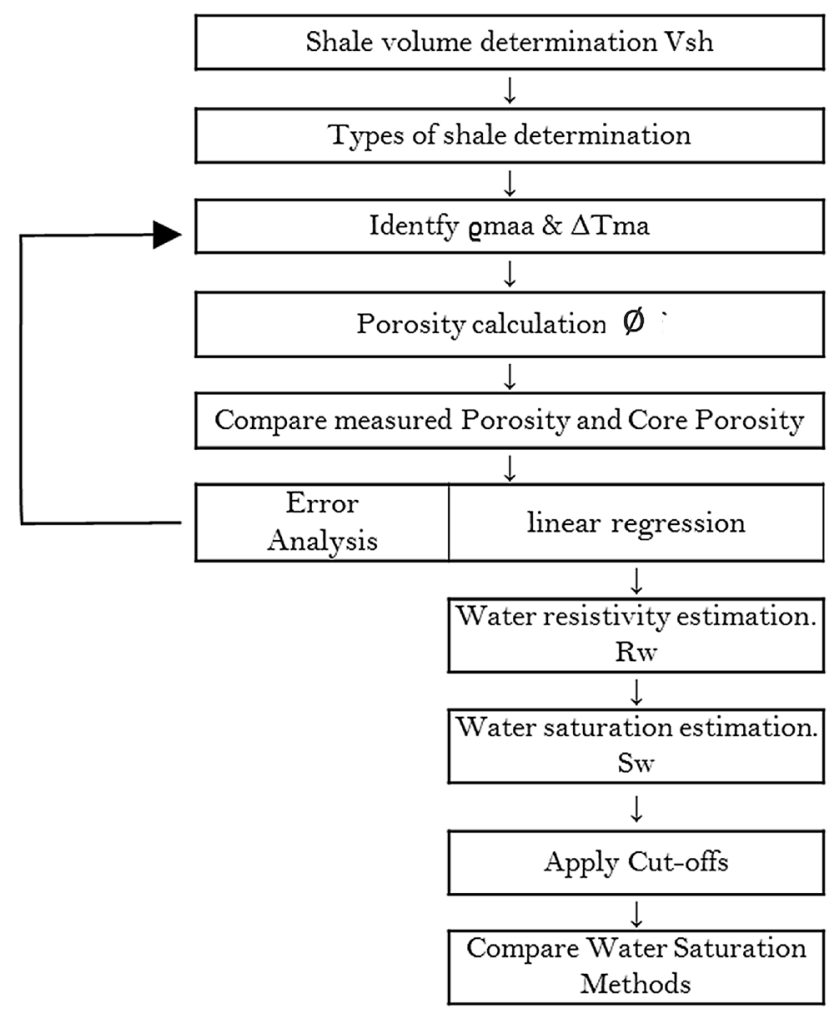

density equations was discussed in Dresser Atlas (1979, 1983). The constants and parameters used in the well log analysis are tabulated in (Table 3).

Ten core samples were acquired for cation exchange capacity test in different intervals of the Bahariya reservoir. The different log readings against each CEC sample are tabulated in Table 4.

\section{Lithology and mineralogy}

Bahariya reservoir is of mixed lithology nature consisting of sand, shale and carbonates. Lithology can be identified from gamma ray, density, neutron and photoelectric logs which are widely available in the field wells. These four $\operatorname{logs}$ are easily used to classify the three Bahariya lithologies, but to differentiate the rich clay sandstone complex mineralogy more logs are required for proper resolve. The accurate mineral solve is requiring advanced logging tools which are not available in NEAG fields. It's difficult for the non-operated wells and expensive to implement. The Bahariya formation consists of different minerals as illite, kaolinite, smectite, chlorite, k-feldspar, calcite, siderite, quartz and mica in variable amounts (Shokry et al. 2015). The core reports and legacy of nearby fields showed the next percentages, quartz (50-60\%), calcite and siderite (0-20\%), kaolinite (5-15\%) and shale matrix (10-20\%) (Wehr et al. 2002; Shokry et al. 2015).

Siltstone is rich clay lithology of finer grain size comparing to sandstone and in order to differentiate from shaley sand and shale spectral gamma ray is fully utilized to differentiate between Bahariya reservoir clay minerals illite, kaolinite, smectite and chlorite. Sonic log is also used essential to differentiate between the carbonate minerals calcite and siderite. A Quanti-Elan model is computed by Techlog software. The calculations are a lengthy linear mathematics where the number of logs equal the number of unknown rock minerals, these hybrid algorithms done by the software. The input parameters for each mineral were set up after a set of iterations to characterize those mixed lithologies. The input parameters of this model are summarized in Table 5. The output minerals are calibrated with composite logs and petrography reports at different intervals to validate this Elan model but the full package of data is limited for the public domain.

Fig. 4 Well logs interpretation workflow

Table 3 Constants and parameters used in the well log analysis

\begin{tabular}{llllllll}
\hline $\mathrm{Gr}_{\text {min }}$ & $35 \mathrm{API}$ & $\mathrm{Gr}_{\max }$ & $120 \mathrm{API}$ & $\mathrm{R}_{\mathrm{w}}$ & $0.035 \mathrm{Ohm} \mathrm{m}$ & $\mathrm{R}_{\mathrm{sh}}$ & $2 \mathrm{Ohm} \mathrm{m}$ \\
$\varrho_{\mathrm{ma}}$ & $2.69 \mathrm{~g} / \mathrm{cm}^{3}$ & $\varrho_{\mathrm{f}}$ & $0.95 \mathrm{gm} / \mathrm{cm}^{3}$ & $a$ & 1 & $a^{*}$ & 0.6 \\
$\Delta T_{\mathrm{ma}}$ & $52 \mu \mathrm{s} / \mathrm{ft}$ & $\Delta T_{\mathrm{f}}$ & $189 \mu \mathrm{st}$ & $n^{*}$ & 1.6 & $m^{*}$ & 2 \\
\hline
\end{tabular}


Table 4 Log readings against cation exchange capacity samples

\begin{tabular}{lllllll}
\hline Sample no. & GR $(\mathrm{API})$ & $\varrho_{\mathrm{b}}(\mathrm{g} / \mathrm{cc})$ & $\emptyset_{\mathrm{N}}(\mathrm{frac})$. & $\Delta T(\mu \mathrm{s} / \mathrm{ft})$ & $R_{\mathrm{t}}(\mathrm{Ohm})$ & $\mathrm{CEC}(\mathrm{S} / \mathrm{m})$ \\
\hline $1 \mathrm{~F}$ & 82 & 2.445 & 0.2 & 93 & 2.28 & -1.09 \\
$2 \mathrm{~F}$ & 84 & 2.4 & 0.24 & 82 & 2.15 & -0.98 \\
$3 \mathrm{~F}$ & 60 & 2.25 & 0.18 & 86 & 1.14 & -0.13 \\
$4 \mathrm{~F}$ & 65 & 2.25 & 0.197 & 86 & 1.54 & -0.07 \\
$5 \mathrm{~F}$ & 86 & 2.36 & 0.226 & 90 & 2.76 & -0.15 \\
$6 \mathrm{~F}$ & 69 & 2.33 & 0.19 & 88 & 1.67 & -0.22 \\
$7 \mathrm{~F}$ & 78 & 2.3 & 0.239 & 97 & 1.11 & -0.63 \\
$8 \mathrm{~F}$ & 73 & 2.26 & 0.21 & 92 & 0.67 & -0.28 \\
$9 \mathrm{~F}$ & 77 & 2.428 & 0.225 & 90 & 1.5 & -0.93 \\
$10 \mathrm{~F}$ & 85 & 2.2 & 0.227 & 90 & 0.81 & -0.11 \\
\hline
\end{tabular}

Table 5 Summary of input parameters of Quanti-Elan model

\begin{tabular}{|c|c|c|c|c|c|c|c|c|}
\hline & DT & GR & DEN & $\mathrm{PE}$ & Thorium Concentration & Potassium Concentration & Shale Volume & Neutron Porosity \\
\hline QIllite & 100 & 270 & 2.52 & 3.5 & 15 & 0.05 & 1 & 0.3 \\
\hline --Kaolinite & 85 & 150 & 2.46 & 1.8 & 12 & 0.005 & 0.6 & 0.32 \\
\hline Smectite & 120 & 250 & 2.12 & 2 & 19 & 0.0015 & N/A & 0.6 \\
\hline 典Chlorite & 75 & 175 & 2.76 & 6.3 & 2.5 & 0.003 & N/A & 0.52 \\
\hline Shale & 117 & 150 & 2.5 & 4.2 & 15 & 0.05 & 0.5 & 0.33 \\
\hline${ }_{*}$ K-Feldspar & 69 & 200 & 2.52 & 2.9 & 10 & 0.13 & 1 & 0.02 \\
\hline${ }_{\times \times} \times N$-Feldspar & 49 & 5 & 2.59 & 1.7 & 0 & 0 & N/A & 0.01 \\
\hline$\because$ Biotite-Mica & 51 & 275 & 2.99 & 6.3 & 25 & 0.08 & N/A & 0.2 \\
\hline 誃Musc-Mica & 49 & 270 & 2.82 & 2.4 & 22 & 0.08 & N/A & 0.2 \\
\hline ㅍㅗㅗCalcite & 51 & 5 & 2.71 & 5.1 & 0 & 0.07 & 0.05 & 0 \\
\hline Siderite & 46 & 0.001 & 3.7 & 14.7 & 0.001 & 0.001 & 0.01 & 0.1 \\
\hline Coal & 120 & 10 & 1.5 & 0.2 & 0 & 0 & $\mathrm{~N} / \mathrm{A}$ & 0.6 \\
\hline $1 / /$ Silt & 65 & 75 & 2.68 & 6 & 8 & 0.07 & N/A & 0 \\
\hline Sand & 62 & 35 & 2.65 & 3.3 & 3 & 0.05 & 0.3 & -0.03 \\
\hline
\end{tabular}

\section{Electrofacies analysis}

Thomas and Stieber (1975) method is used to identify the different types of shale by plotting volume of shale $\left(V_{\text {sh }}\right)$ versus total porosity $\left(\emptyset_{t}\right)$ (Fig. 5). Structure and dispersed shales are rarely found relative to the other types. Clean sand, laminated sand and siltstone are the three main categories observed in the Bahariya reservoir. The laminated shaley sand lithology is an intercalation of sand and shale layers on small scale commonly at or below the $\log$ resolution which will affect the log readings. These intercalations known as hetrolithics or sand flats are the key element to evaluate the Bahariya reservoir potential (El-Bagoury et al. 2017). The siltstone has finer grain size and higher degree of shaliness.

\section{Shaley sand models}

This work is done after characterizing the clay types in the Bahariya reservoir to review the calculated water saturation using the appropriate models. Calculated water saturation by shaley sand models is significantly decreased by $30 \%$ from water saturation by Archie which is matching with production data (dry oil). The next section will discuss these methods.

\section{Indonesian model}

The Indonesia equation by Poupon and Leveaux (1971) was developed for shaley sand reservoirs in fresh formation water with salinities less than $20,000 \mathrm{NaCl}$ ppm. The water saturation is function of deep resistivity $\left(R_{\mathrm{t}}\right)$, while 


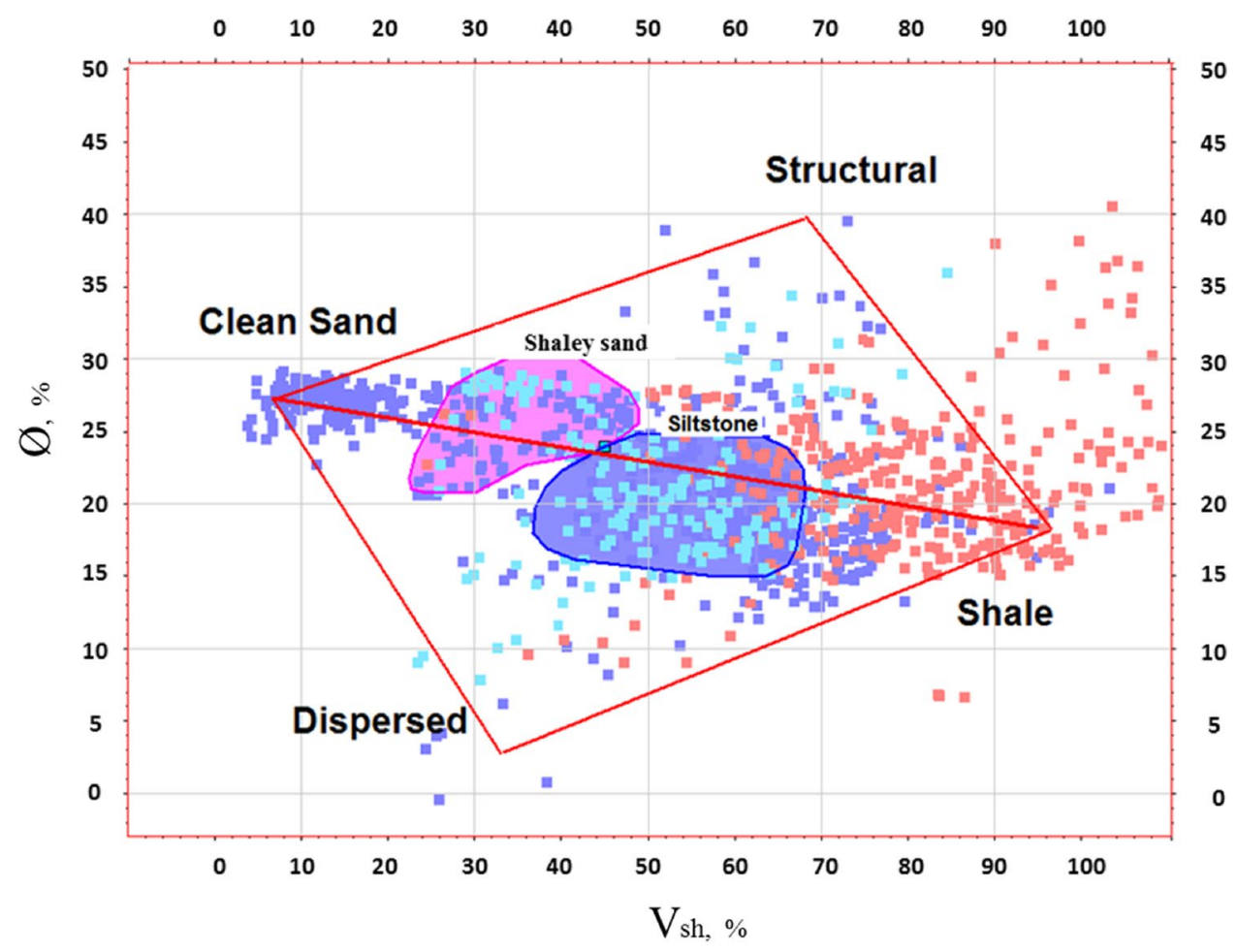

Fig. 5 Thomas Stieber plot showing the characteristics of Bahariya electrofacies

the resistivity of shale $\left(R_{\mathrm{sh}}\right)$ is taken from resistivity logs against pure shale zones.

$\frac{1}{R_{\mathrm{t}}}=S_{\mathrm{w}}^{n / 2}\left[\frac{V_{\mathrm{sh}}^{\left(1-\left(V_{\mathrm{sh}} / 2\right)\right)}}{\sqrt{R_{\mathrm{sh}}}}+\left(\frac{\emptyset_{\mathrm{e}}^{m / 2}}{\sqrt{a * R_{\mathrm{w}}}}\right)\right]$

where $R_{\mathrm{t}}$ : true (deep) resistivity in the un-invaded zone (Ohm-m); $S_{\mathrm{w}}$ : un-invaded zone water saturation (fraction); $n$ : saturation exponent; $V_{\mathrm{sh}}$ : volume of shale (fraction); $R_{\mathrm{sh}}$ : resistivity of shale $(\mathrm{Ohm}-\mathrm{m}) ; \emptyset_{\mathrm{e}}$ : effective porosity (fraction); $m$ : cementation factor; $a$ : constant multiplier; $R_{\mathrm{w}}$ : formation water resistivity (Ohm-m).

\section{Simandoux model}

Simandoux studied the clay volumes effect on reducing rock matrix conductivity and the water saturation. Simandoux experiments on 1963 discussed clay effect on homogeneous mixtures of sorted sand and natural clay in various proportions which artificially mixed on laboratory.

$$
\begin{aligned}
S_{\mathrm{w}}= & \frac{a * R_{\mathrm{w}} *\left(1-V_{\mathrm{sh}}\right)}{2 \emptyset^{m}}\left[-\frac{V_{\mathrm{sh}}}{R_{\mathrm{sh}}}\right] \\
& +\left(\sqrt{\left(\frac{V_{\mathrm{sh}}}{R_{\mathrm{sh}}}\right)^{2}+\left(\frac{4 \emptyset^{m}}{a * R_{\mathrm{w}} * R_{\mathrm{t}} *\left(1-V_{\mathrm{sh}}\right)}\right)}\right)
\end{aligned}
$$

where $S_{\mathrm{w}}$ : un-invaded zone water saturation (fraction); $V_{\mathrm{sh}}$ : volume of shale (fraction); $R_{\mathrm{sh}}$ : resistivity of shale (Ohm$\mathrm{m}) ; R_{\mathrm{w}}$ : Formation water resistivity $(\mathrm{Ohm}-\mathrm{m}) ; R_{\mathrm{t}}$ : true deep resistivity in the un-invaded zone $(\mathrm{Ohm}-\mathrm{m})$; $\varnothing$ : effective porosity (fraction); $(a)$ and $(m)$ are constants representing multipliers and cementation factors, respectively.

\section{Waxman Smith model}

Waxman and Smits method based on the laboratory measurements for cation exchange capacity (CEC) versus shale content. CEC measured on core samples are correlated with effective porosity and shale content calculated from logs. Logderived porosity and shale volume are usually necessary for accurate water saturation calculations.

The equation is as follows: 
$\frac{1}{R_{\mathrm{t}}}=\frac{S_{\mathrm{w}}^{2}}{F * R_{\mathrm{w}}}+\frac{B Q_{\mathrm{v}} * R_{\mathrm{w}}}{F}$

where $R_{\mathrm{t}}$ : true resistivity in the un-invaded zone (Ohm-m); $S_{\mathrm{w}}$ : the un-invaded zone water saturation (fraction); $R_{\mathrm{w}}$ : the formation water resistivity (Ohm-m); $F$ : formation factor. (1/ $\left.\emptyset^{m^{*}}\right)$ where $m^{*} \neq m ; Q_{\mathrm{v}}$ : cation exchange capacity volumetric (Unite per liter); $B$ : Equivalent cationic conductance of a sodium ion $(\mathrm{L} \mathrm{S} / \mathrm{m})$ can be calculated by next equation to relate $B$ to formation temperature (T) Celsius degrees and water resistivity, $R_{\mathrm{w}}$, as published by Waxman and Thomas (1974), is as follows:

$$
\begin{aligned}
B= & \left(-1.28+0.255^{*} T-0.0004059 * T^{2}\right) \\
& \left(1+\left(0.04^{*} T-0.27\right)^{*} R_{\mathrm{w}}^{1.23}\right)
\end{aligned}
$$

Normalized Waxman-Smits equation $\left(F=1 / \emptyset^{m}\right)$, where $\emptyset$ is derived from the density log and corrected for hydrocarbon effects. Water saturation is calculated in total interconnected pore spaces (Juhasz 1981). Estimating the apparent water conductivity according to the next equation;

$\frac{\emptyset^{m *}}{R_{\mathrm{t}}}=B Q_{\mathrm{v}}+\frac{1}{R_{\mathrm{w}}}$

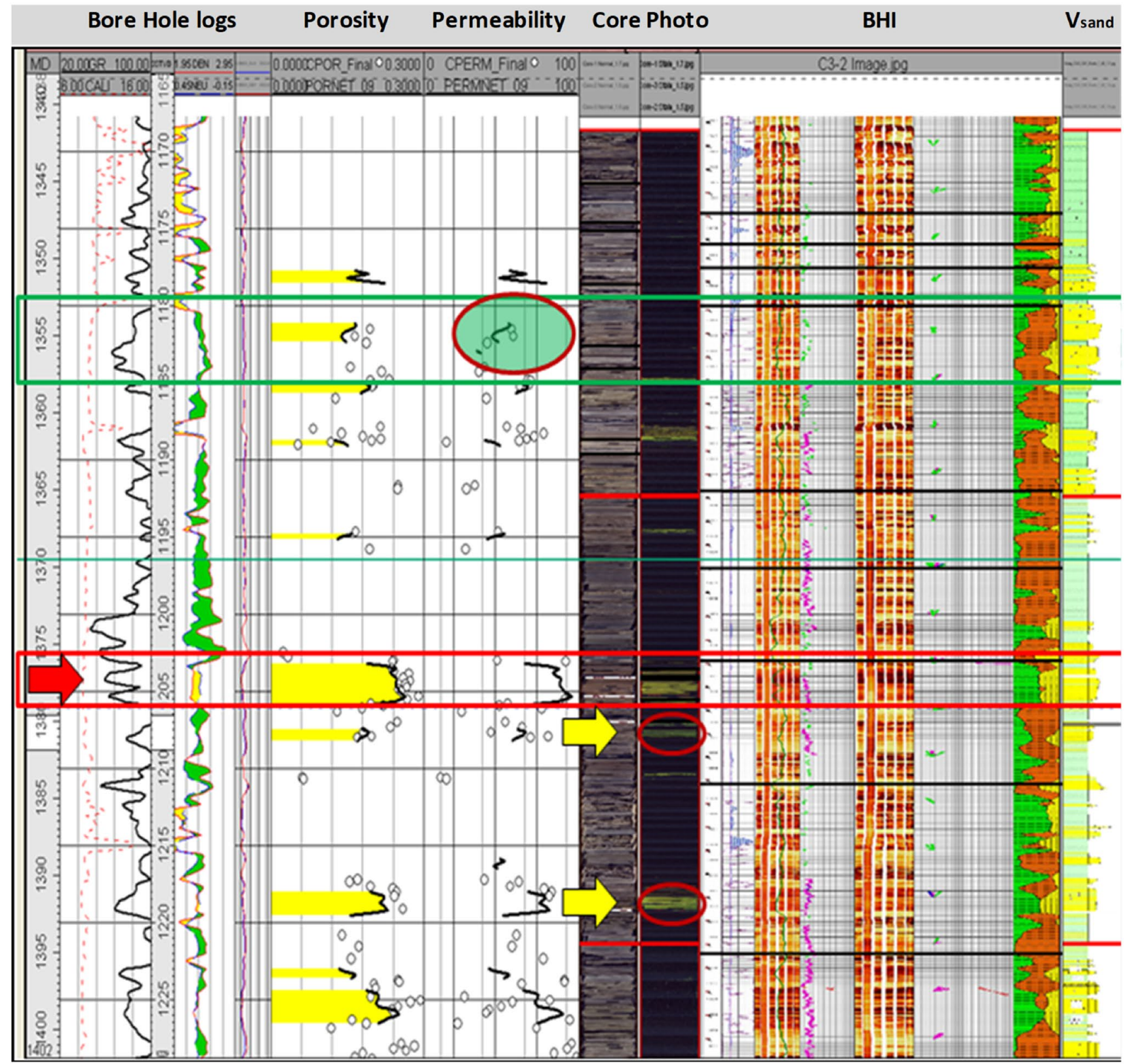

Fig. 6 Well-1 integrated plot for well logs, core analysis, core photographs, borehole Image and lithology modified from ElBelisy et al. (2010) 
where $m^{*}$ : modified cementation factor; $\varnothing$ : formation porosity (fraction); $R_{\mathrm{t}}$ : true resistivity in the un-invaded zone $(\mathrm{Ohm}-\mathrm{m}) ; B Q_{\mathrm{v}}$ : Cation exchange capacity (Unite per liter); $R_{\mathrm{w}}$ : water resistivity (Ohm-m).

The cation exchange capacity is calculated by the equation;

$B Q_{\mathrm{v}}=B C \frac{\left(\emptyset_{N}-\emptyset_{T}\right)}{\emptyset_{T}}$

$\mathrm{BC}$ is the slope of this relation at $100 \%$ water saturation of the relation between apparent water conductivity $\left(\frac{\emptyset^{m *}}{R_{t}}\right)$ versus apparent clay fraction conductivity $\left(\frac{\emptyset_{N}-\emptyset_{T}}{\emptyset_{T}}\right)$.

\section{Low resistivity pay}

Low resistivity pay module (also called Low ReP) is considered to evaluate laminated sand/shale reservoirs. The application of this method into dry oil productive zones characterized by high clay content to correct the excess conductivity rise compared with rock (Darling 2005).

Low resistivity pay module workflow applied in steps as follows;

1. The input curves require at least GR, density, neutron and resistivity curves.

2. Estimating $V_{\mathrm{sh}}$ from neutron/density logs.

3. Define the cutoff limit.

4. Calibrate with core measurements or test results (the simple calibration is the ultraviolet core photographs that affected by oil staining (Fig. 6).

5. The shale parameters estimated for low resistivity pay are as follows;

\begin{tabular}{llll}
\hline Parameters & $\begin{array}{l}\text { Gamma ray } \\
\text { API }\end{array}$ & $\begin{array}{l}\text { Bulk density } \\
\left(\mathrm{g} / \mathrm{cm}^{3}\right)\end{array}$ & Neutron porosity \\
\hline $\begin{array}{l}\text { Shale param- } \\
\text { eters }\end{array}$ & 110 & 2.45 & 0.35 \\
\hline
\end{tabular}

6. The anisotropy correction is the key factor in which this method was the apparent vertical resistivity corrected to remove the laminated clay effect, which found approximately equals 1.5 the horizontal resistivity.

$\frac{R_{\mathrm{v}}}{R_{\mathrm{h}}} \cong 1.5$

\section{Results}

The scope of this work is to identify the petrophysical properties for Bahariya shaley sands specially water saturation $\left(S_{\mathrm{w}}\right)$ and compare the log evaluation results to core measurements for calibration. The degree of shaliness is classified into low, medium and high. The overall reservoir shows non-clean formation trend and different mineral composition. Various water saturation models are considered in petrophysical evaluation, and the average error between the $\log$ results and core data is highlighted.

\section{Porosity calibration}

The calculated water saturation is function of log porosity. The error in $\log$ porosity will affect the quality of water saturation calculation. Thus, the log porosity is calibrated with core porosity measured in laboratory. This calibration is applied to the results to check for minor errors. This step is providing quality assurance to results and linking between different petrophysical methods (Darling 2005; Schön 2011). The calibration is significant for porosity calculation in future wells from logs only in the non-cored wells. Log porosity and core porosity plotted against each other in two different plots

(1) Log plot, the log porosity is plotted with same scale as red circles in the same track of log porosity for visual correlation (Fig. 7).

(2) $X, Y$ plot, the log porosity is plotted on $X$ axis versus $\log$ porosity on $Y$ axis to quality control the best fit line (Fig. 8).

There is a strong match and harmony between the calculated log porosity and measured porosity form core samples up to $85 \%$ of the data.

\section{Shaley sand count}

The bore hole image (BHI) has a high vertical resolution ( 0.2 in. in water base mud and $0.4 \mathrm{in}$. in oil base mud) while the conventional logs are more than 8 in. (Schlumberger technology forum 2010). High-resolution bore hole image is used in net sand count to calibrate neutron/density cross-over and Thomas Stiber plot to fine-tune the shaley sand cutoff. Each electrofacies is calibrated by BHI using the separation between neutron and bulk density logs (Fig. 9). Each code represents different facies;

Code 1 Clean sand where clear cross over between the neutron and bulk density logs.

Code 2 Shaley sand (sand flat) where the two logs are closer and no big gaps between.

Code 3 Siltstone where the logs have narrow negative cross over.

Code 4 Shale where the logs separation is clear negative crosses over. 
Fig. 7 Log plot of porosity versus core porosity

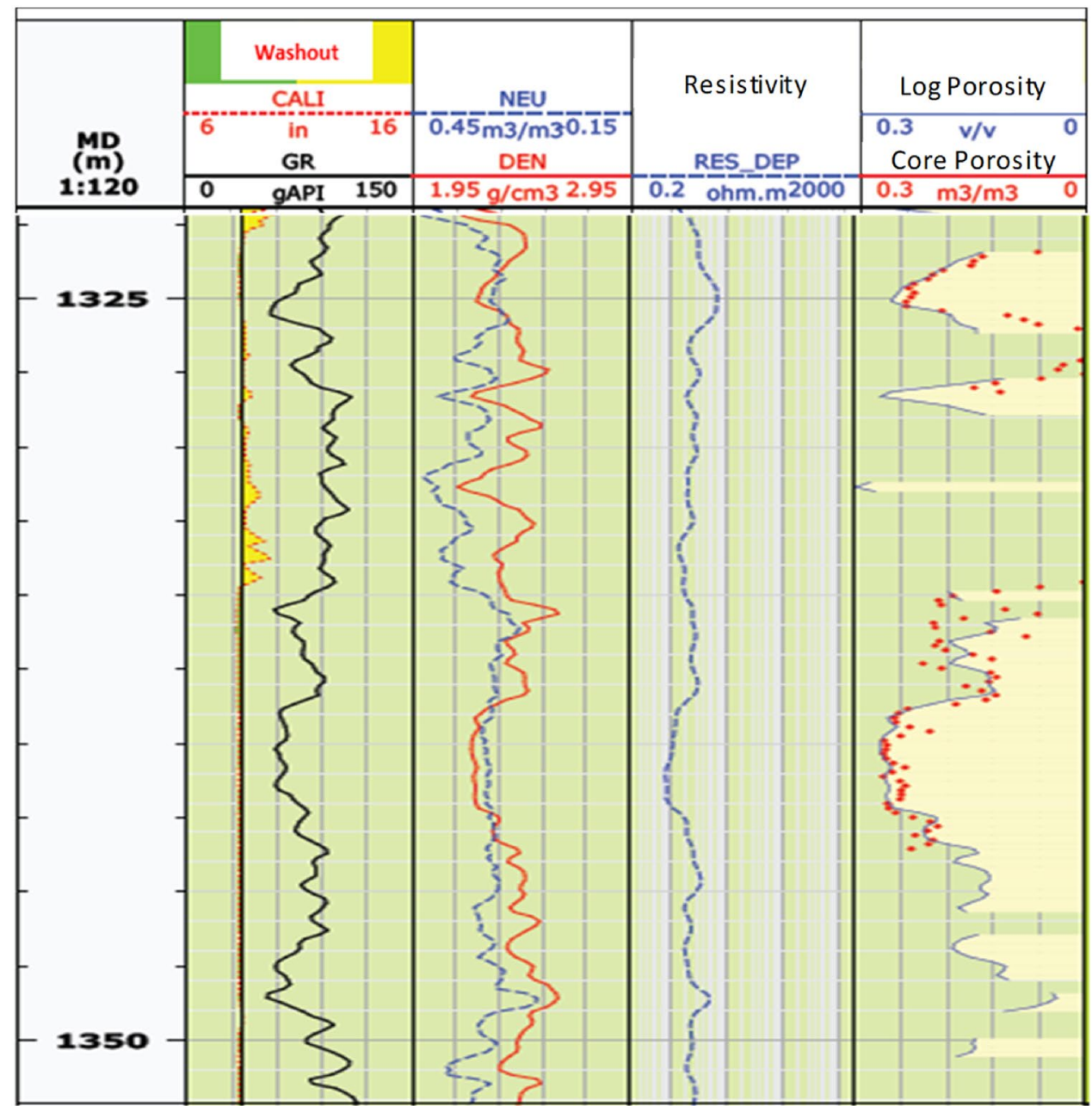

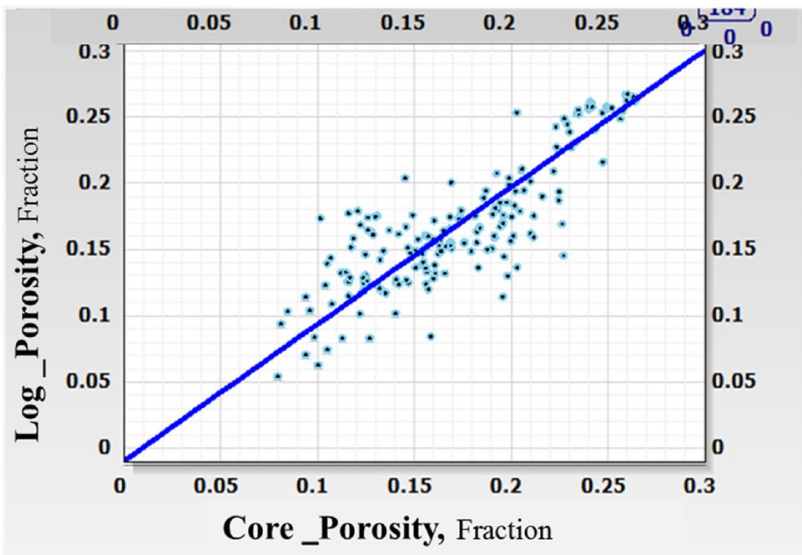

Fig. $8 X, Y$ plot of log porosity versus core porosity

\section{Elan model}

Elan model (with complete log data set) is used to differentiate between different pore filling minerals especially clay minerals (kaolinite, illite and k-feldspar) from other finer shales in rock matrix. The Elan model in this paper is targeting accurate net pay sand and digital mineral components against all intervals (Fig. 10). The output minerals curves of Bahariya reservoir showed total seven common minerals after the modeling process. These minerals are Illite, kaolinite, calcite, siderite, quartz (sand), shale and rare amount of k-feldspar while chlorite and smectite are absent. Few bad hole flags are highlighted in red color due to washout. There is high concentration of kaolinite in few intervals of lower Bahariya, which increases the recorded gamma ray and density logs (Fig. 10).

\section{Discussion}

The shaley sands are the common electrofacies in Bahariya reservoir if shale is ignored with up to $27 \%$ from total. Structure and dispersed shales are rare and does not exceed $3 \%$. The carful inspection of shaley sands in the core photographs ultraviolet light showed oil staining as same as 


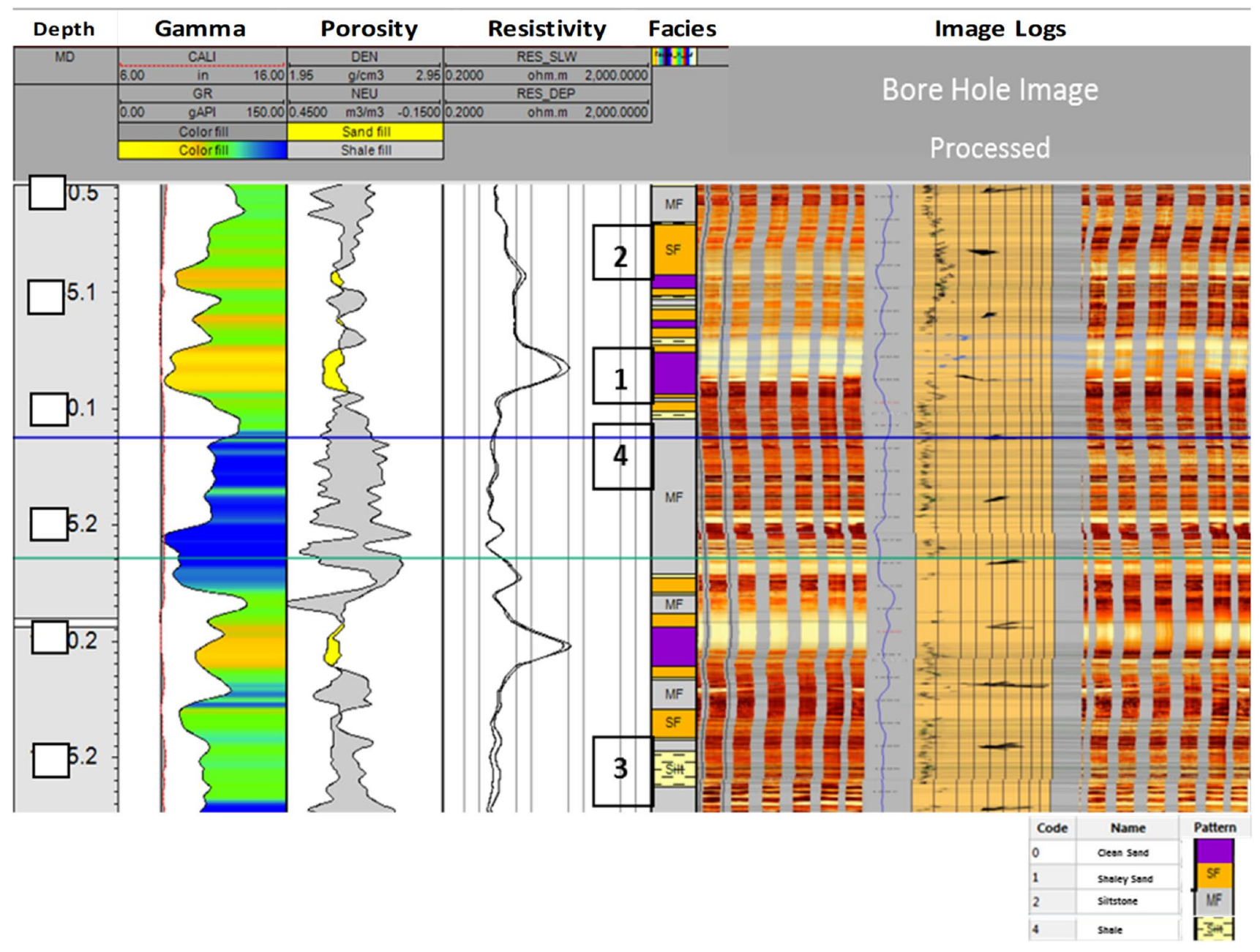

Fig. 9 Well-1 bore hole logs gamma ray, density, neutron, resistivity and electrofacies discrete logs integrated with bore hole image logs

the clean sands (Fig. 6). Thus, shaley sands can be added to the net pay reservoir and selected for further perforation. On the other hand, the siltstone electrofacies does not exceed $11 \%$ in total of Bahariya Formation. Generally, siltstone does not show positive oil staining on ultra-violet light like shaley sands as the storage capacity of siltstone is limited in these types of rocks (El Sayed et al. 2019). Therefore, the siltstone electrofacies is not considered as part of the net reservoir (Fig. 11).

Storage and flow capacities of Bahariya reservoirs are affected rigorously by amount of pore filling minerals especially calcareous cements (Shokry et al. 2015; El Sayed et al. 2019); the carbonate cements influence the CEC as well. Carbonate minerals (calcite and dolomite) are interrupting the correlation between volume of shale, porosity and cation exchange capacity (Figs. 12, 13).

The CEC can be expressed by the equation;

$\left.\mathrm{CEC}^{*}=-11.635\left[(1-\emptyset)^{*} V_{\mathrm{sh}}\right)\right]^{3.49}$
Core conductivity measurements give range of CEC from -0.07 to $-1.08 \mathrm{~S} / \mathrm{m}$. Waxman smith cementation factor $\left(m^{*}\right)$ is ranging from 0.7 to 1.6. This method benefits from the three reservoir groups mentioned earlier (1) clean sand, (2) shaley sand (sand flat) and (3) siltstone. CEC is integrated with each type in Table 6.

Four methods were applied to calculate water saturation from bore hole logs. The comparison between these methods is proving a conclusion about the true water saturation. The calculated error in the water saturation by Indonesia is higher than other methods. Simandoux gives better water saturation results than Indonesia and LRp, which are showing uncertainty above and below the core measurements. Waxman smith showed calibrated results comparing with Dean stark saturation measured on core for the same intervals. Waxman smith and Simandoux methods enhance the water saturation to reasonable values matching the core measurements although there is still small error that does not exceed $9 \%$ of the true saturation mainly observed at very low porosity (Table 7). The advantage of integrating all these 


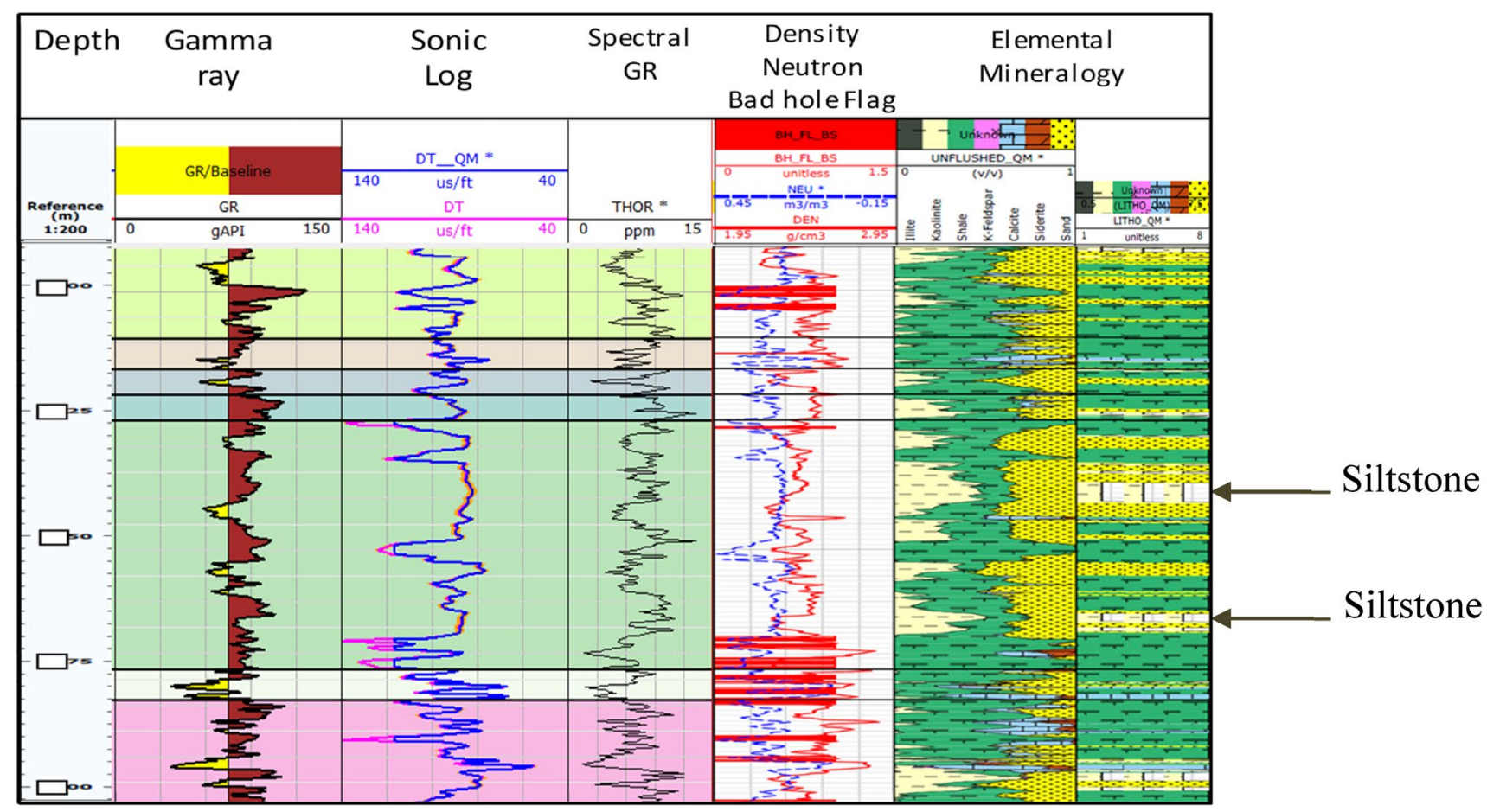

Fig. 10 Elan model input logs, output mineralogy, and interpreted lithology of pilot well

Fig. 11 Bahariya histogram for types of shale

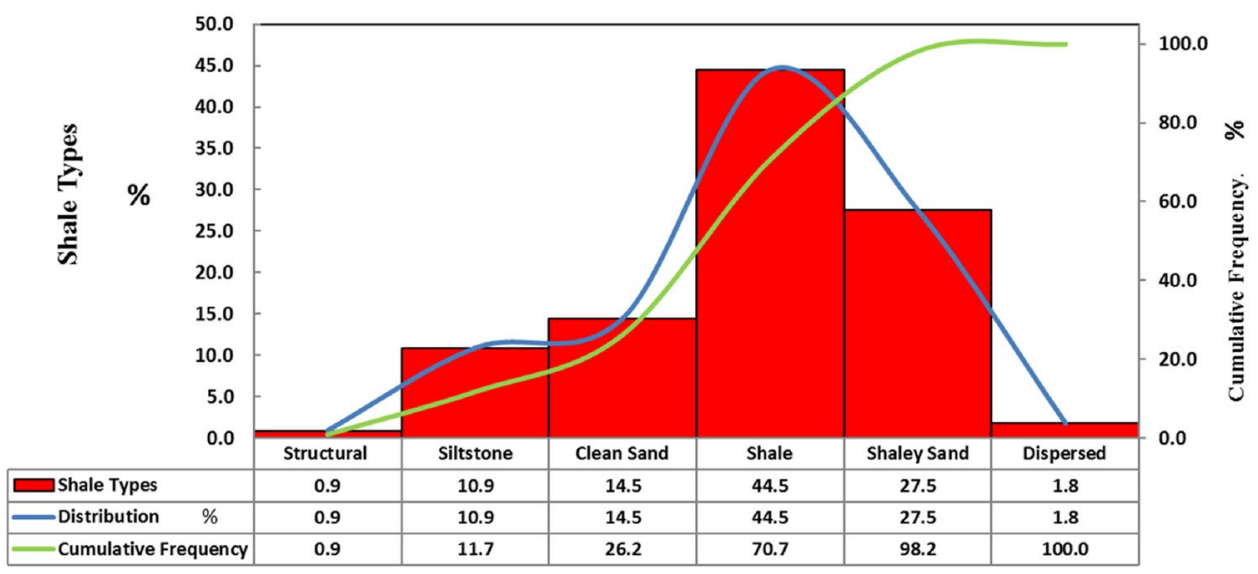

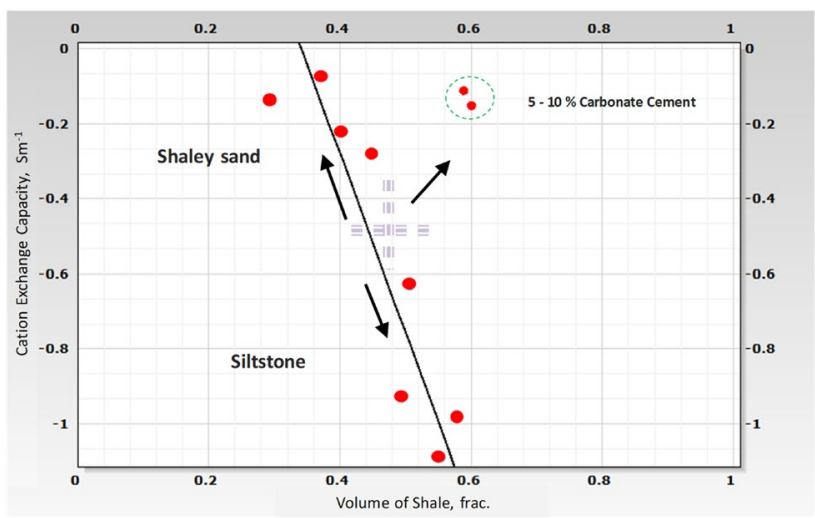

Fig. $12 \mathrm{CEC}$ versus volume of shale in Bahariya reservoir

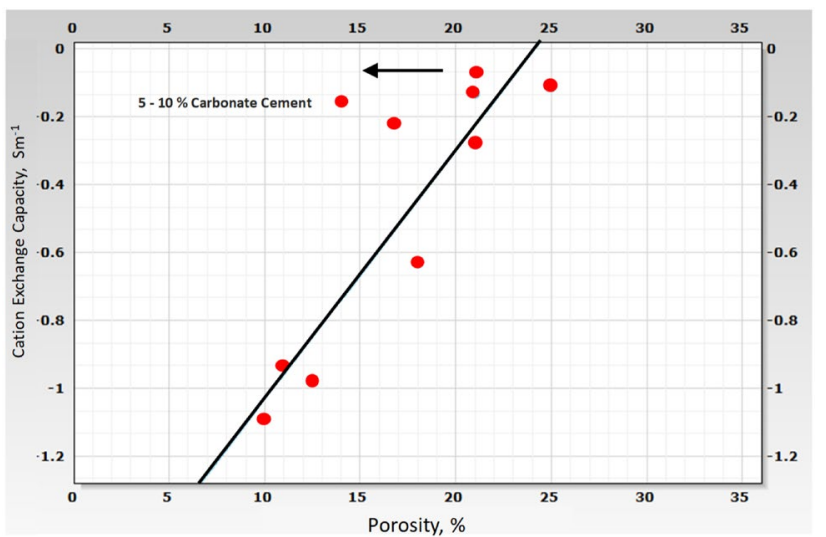

Fig. 13 CEC versus porosity of Bahariya reservoir 
Table 6 Cation exchange capacity integrated characterization

\begin{tabular}{|c|c|c|c|c|c|c|c|c|c|c|}
\hline Shale type & $\mathrm{CEC}$ & & $V_{\text {silt }}$ & $V_{\text {sand }}$ & & & le $:$ & silt & Vsand & \\
\hline & $\left(\mathrm{S} \mathrm{m}^{-1}\right)$ & $\%$ & $\%$ & $\%$ & 0 & 20 & 40 & 60 & 80 & 100 \\
\hline Clean sand & 0 to -0.1 & $<25$ & $5-10$ & 70 & & & & & & \\
\hline Shaley sand & -0.15 to -0.5 & $30-40$ & $10-20$ & 60 & & & & & & \\
\hline Siltstone & -0.5 to -0.9 & $>50$ & $20-30$ & $<50$ & & & & & & \\
\hline
\end{tabular}

Table 7 Integrated water saturation results of core and $\log$ interpretation on same plugs

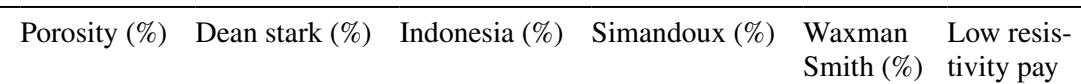

(\%)

\begin{tabular}{lrrlllr}
\hline Sample-A & 18.8 & 18.1 & 25.5 & 20.0 & 12.94 & 22.22 \\
Sample-B & 11.1 & 20.1 & 30.0 & 21.75 & 16.81 & 35.71 \\
Sample-C & 21.4 & 13.6 & 33.0 & 22.0 & 20.73 & 6.67 \\
Sample-D & 6.2 & 26.3 & 35.0 & 25.0 & 35.23 & 8.11 \\
Sample-E & 16.3 & 20.7 & 30.7 & 23.76 & 15.53 & 17.86 \\
Average error & & 0 & 11.08 & 2.74 & 0.49 & -1.65 \\
\hline
\end{tabular}

Fig. 14 Well-1 litho-saturation cross-plot of the Bahariya reservoir in NEAG-1

Scale 1:240 (1295-1352 m)

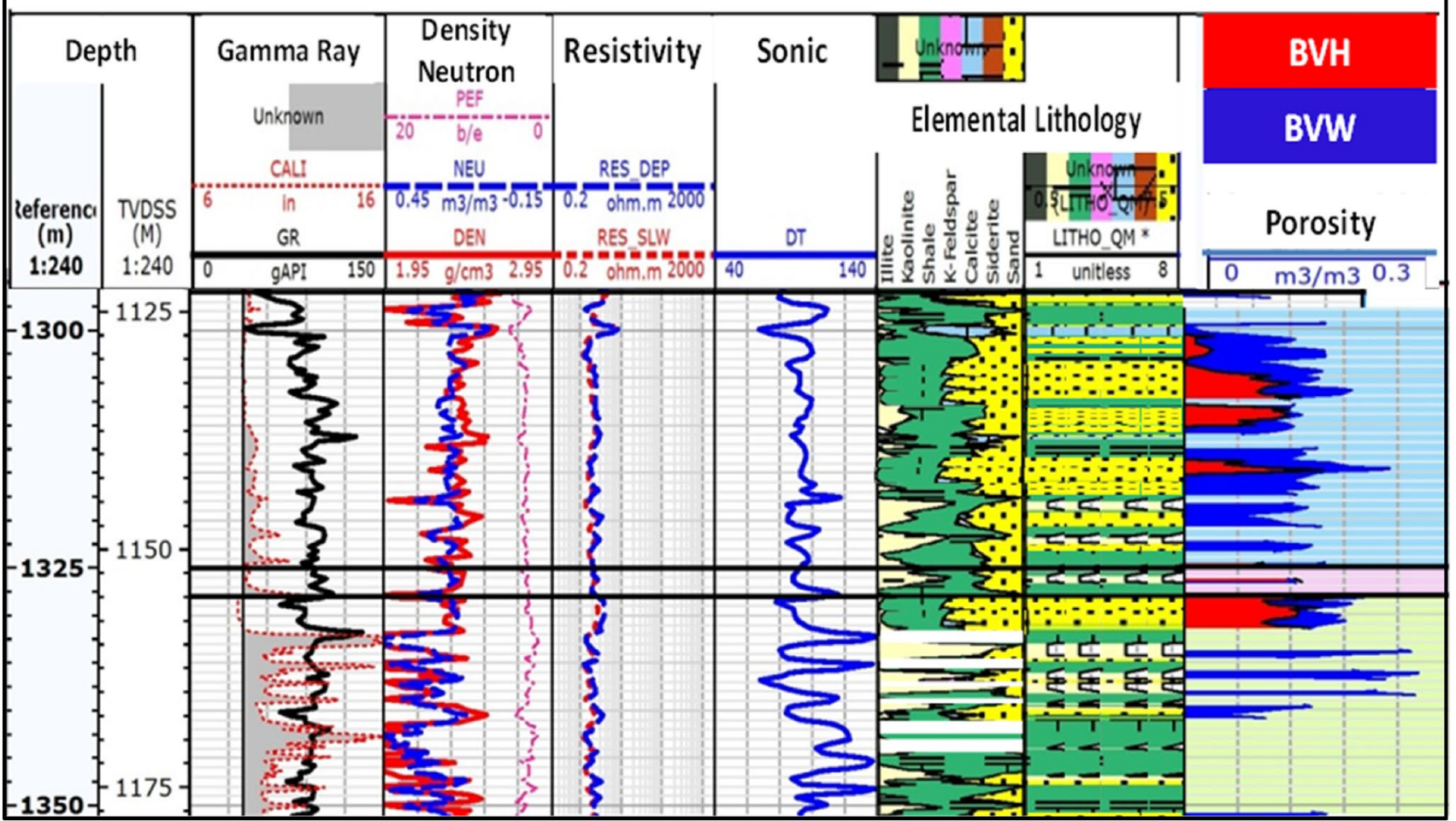




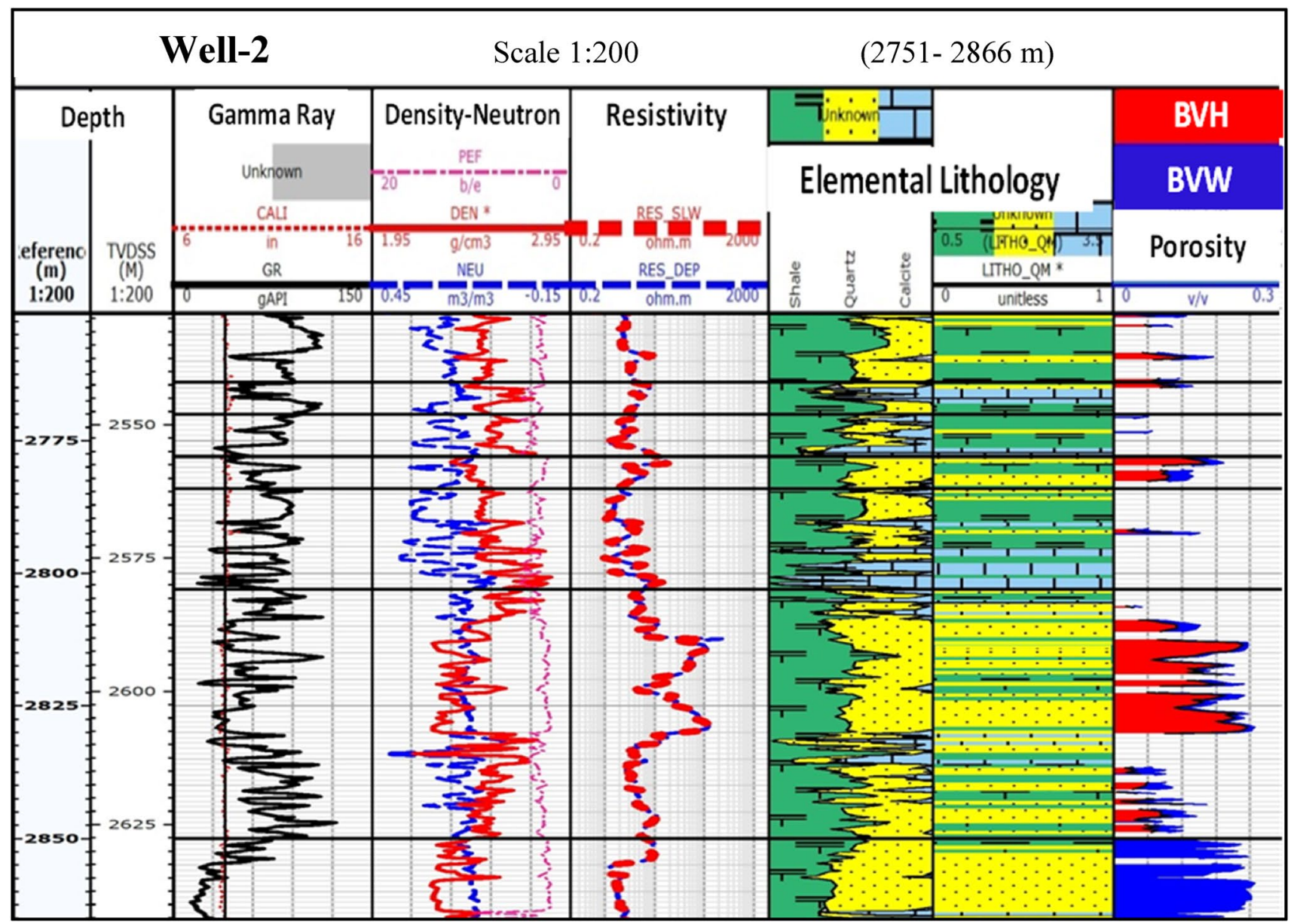

Fig. 15 Well-2 litho-saturation cross-plot of the Bahariya reservoir in NEAG-2

methods will be clear in water-bearing reservoir intervals, as no pseudo-hydrocarbon saturation will appear (Figs. 14, 15).

The results showed variation in water saturation, Simandoux provides a reasonable correlation with saturation in core; however, this method is only log-derived regardless the shale distribution. Simandoux method looks uniform in all Bahariya shale types without unique clay mineral characterization as Waxman smith method. The Waxman smith error is very small due to the effective calibration with CEC measurements. The low resistivity pay method gives an optimistic correction to clay content based on the percentage of shale intercalations identified from bore hole images which give the applied vertical

Table 8 Results of different saturation methods

\begin{tabular}{lllll}
\hline Method & Indonesia & Simandoux & $\begin{array}{l}\text { Waxman } \\
\text { Smith }\end{array}$ & $\begin{array}{l}\text { Low resis- } \\
\text { tivity pay }\end{array}$ \\
\hline $\begin{array}{l}\text { Average } \\
\begin{array}{c}\text { water satu- } \\
\text { ration (\%) }\end{array}\end{array}$ & 30.84 & 22.50 & 20.25 & 18.11 \\
\hline
\end{tabular}

correction assuming homogeneous layers and unique clay resistivity response. The LRp method is mainly based on that assumption; however, it may not be the case for the Bahariya reservoir. The average water saturation for each tested method is found in Table 8 .

\section{Conclusions}

The derived water saturation by different petrophysical models from bore hole logs is compared to core measurements in the same intervals. Three types of electrofacies are detected in Bahariya reservoir rocks subjected to clay percentage, clean sandstone, shaley sandstones and siltstones. The high-resolution bore hole image and Quanti-Elan model are used to validate and calibrate the three electrofacies. Shaley sand of the Bahariya reservoir is rich in kaolinite, illite and carbonate cement, which increases the matrix density up to $2.69 \mathrm{~g} / \mathrm{cc}$. Clean and shaley sand electrofacies are considered the best reservoir with average porosity $26 \%$ and $21.5 \%$, respectively, while siltstone is considered as poor 
reservoir characterized by average porosity $17.6 \%$ and high clay content (35-55\%). The upper part of Bahariya reservoir showed differences in porosity because of variation in grain size and clay contents as result of fining and coarsening upward associated with cemented layers sometimes. The interpreted electrofacies are integrated with CEC to apply Waxman smith method. The clean sand reveals neglected CEC while shaley sands have CEC ranging from -0.15 to $-0.5 \mathrm{~S} / \mathrm{m}$ and siltstone from -0.5 to $-0.9 \mathrm{~S} / \mathrm{m}$. The empirically calculated CEC from volume of shale and porosity gives coefficient of correlation higher than 0.9 which can be extended to other fields. Waxman smith approach gives minimum error which is considered the best method for calculating water saturation in Bahariya shaley sands followed by Simandoux in second place. Simandoux method showed relatively small error (2-3\%) comparing to Waxman smith and dean stark. Generally, Simandoux method gives good match for all porosities below $21 \%$. The other methods as Indonesia and $\mathrm{LR}_{\mathrm{p}}$ are not recommended in the Bahariya formation because Indonesia gives higher $S_{\mathrm{w}}$ estimations and LRp gives low $S_{\mathrm{w}}$ results.

Acknowledgements Authors acknowledge EGPC and BAPETCO for giving the permission to use the technical data, Special thanks to our colleges in BAPETCO exploration and petroleum engineering departments for data sharing and integration.

Open Access This article is licensed under a Creative Commons Attribution 4.0 International License, which permits use, sharing, adaptation, distribution and reproduction in any medium or format, as long as you give appropriate credit to the original author(s) and the source, provide a link to the Creative Commons licence, and indicate if changes were made. The images or other third party material in this article are included in the article's Creative Commons licence, unless indicated otherwise in a credit line to the material. If material is not included in the article's Creative Commons licence and your intended use is not permitted by statutory regulation or exceeds the permitted use, you will need to obtain permission directly from the copyright holder. To view a copy of this licence, visit http://creativecommons.org/licenses/by/4.0/.

\section{References}

Abdel Aal AA, Moustafa AR (1988) Structural framework of the Abu Gharadig basin, Western Desert, Egypt. 9th E.G.P.C. Conference, Cairo, p 37

Abu Shady AN, El-Shishtawy AM, Abdel Hameed AT (2010) Reservoir characterization of the Upper Cretaceous Bahariya formation, Khalda ridge, north Western Desert, Egypt. In: Proceedings of the sixth international symposium on geophysics, Tanta, Egypt, pp 34-46

American Petroleum Institute (API) (1998) Recommended practices for core analysis, recommended practice 40, 2nd edn. API, Dallas

Atlas Dresser (1979) Log interpretation charts. Dresser Industries Inc., Houston

Atlas Dresser (1983) Log interpretation charts. Dresser Industries Inc., Houston

Bakr A, Le Varlet X, Postuma W, Karaaly H (2010) Fast-track maturation and development of the Al Fadl \& Al Qadr Fields, two new discoveries, NEAG East, Western Desert, Egypt. Badr Petroleum Company, SPE 128009

Bakry G (1994) Transgressive/regressive reservoirs and implication for hydrocarbon accumulation: Abu Roash ' $G$ ', Abu Gharadig Basin, Western Desert, Egypt. In: 12th petroleum exploration and production conference, pp 368-386

Bakry G (2005) Facies modelling and hydrocarbon trapping mechanism of some selected upper cretaceous-tertiary reservoirs Badr El-Din and Sitra concessions, Western Desert, Egypt. PhD thesis. Faculty of Science, Al-Azhar University, Egypt, pp 16, 19

Bardon C, Pied B (1969) Formation water saturation in shaly sands. In: SPWLA 10th annual, logging symposium transactions, Houston, Texas, 25-28 May, paper Z

Bassiouni Z (1994) Theory, measurement, and interpretation of well logs. In: Henry L (ed) Dohorty memorial found of AIME. Society of Petroleum Engineers, London, pp 11-24

Bayoumi T (1996) The influence of interaction of depositional environment and syn-sedimentary tectonics on the development of some Late Cretaceous source rocks, Abu Gharadig Basin, Western Desert, Egypt

Catuneanu O, Khalifa MA, Wanas HA (2006) Sequence stratigraphy of the Lower Cenomanian Bahariya Formation, Bahariya Oasis, Western Desert, Egypt. Sediment Geol 190(1-4):121-137

Crain's Petrophysical Handbook (2000) by E. R. (Ross) Crain, Copyright 1978-2000, www.spec2000.net. ISBN 0-9734171-1-0

Darling T (2005) Well logging and formation evaluation. Elsevier, London, pp 115-119

Dean EW, Stark DD (1920) A convenient method for the determination of water in petroleum and other organic emulsions. J Ind Eng Chem 12(5):486-490

Dolson JC, Shann MV, Matbouly S, Harwood C, Rashed R, Hammouda H (2001) The petroleum potential of Egypt. In: Halbouty M (ed) Petroleum provinces of the twenty-first century, AAPG Memoir 74, pp 453-482

EGPC (Egyptian General Petroleum Corporation) (1992) Western Desert oil and gas fields (A comprehensive Overview), Cairo, Egypt, $\mathrm{p} 40$

El Ayouty MK (1990) Petroleum geology. In: Said R (ed) The geology of Egypt. AA Balkema, Rotterdam, pp 567-599

El-Bagoury MA (2015) Quantitative well log analysis for formation evaluation at Assil Field, Western Desert, Egypt. MSc thesis. Faculty of Science, Al-Azhar University, Egypt

El-Bagoury MA (2019) Reservoir characterization using bore hole logs and core data for Neag-1, -2 and -3, Western Desert, Egypt. PhD thesis. Faculty of Science, Ain Shams University, Egypt

El-Bagoury MA, Fahmy M, Kamal M, Saad A, VanHeeswijk V, Kharboutly R (2017) Key learnings from re-development activity and waterflood EOR of mature brown field: heterogeneous compartmentalized reservoir case study, Western Desert, Egypt. SPE188574-MS, ADIPEC 2017

ElBelisy M, Bakr A, Ahmed I, Albaaj E, Wahdan M (2010) Special core analysis for integrated static \& dynamic reservoir modeling, Bapetco, NEAG-1 Field, SPE 128031-PP

El Sayed NA, El Sayed AA (2015) Petrophysical modeling for the Bahariya Formation, Egypt. Procedia Earth Planet Sci 15:518-525

El Sayed AMA, Mouse SA, Higazi A, Al-Kodsh A (1993) Reservoir characteristics of the Bahariya Formation in both Salaam and Khalda oil fields, Western Desert, Egypt

El Sayed AMA, El Bagoury M, El Sayed NA, Shebl A (2019) Hydraulic flow units of some studied Bahariya samples: Abu Gharadiq Basin, W. Desert, Egypt, World multidisciplinary earth science symposium WMESS 3-7 Sep 2018, Prague, Czech Republic, Published in Institute of Physics Journal (IOP)

Franks GD (1982) Stratigraphic modeling of Upper Cretaceous sediments of Bahariya Oasis, Sixth EGPC Exp. Seminar, Cairo, p 21

Google Earth Maps (2012) Data SIO, NOAA, US, Navy, 2012 Google 
Halisch M, Weller A, Sattler C, Debschütz W, El-Sayed AMA (2009) A complex core- $\log$ case study of anisotropic sandstone, originating from Bahariya Formation, Abu Gharadig basin, Egypt. Petrophysics 50(6):478-497

Hegazy M, Labib AM (1996) Effect of mineralogy on water saturation and productivity of Khalda oil field, tenth exploration and production conference EGPC

Hill HJ, Milburn JD (1955) Effect of clay and water salinity on electrochemical behavior of reservoir rocks. Petroleum Branch of AIME $532-\mathrm{G}$

Ibrahim H (2014) Structural style and hydrocarbon trapping of East Bahariya, using $3 \mathrm{~d}$ seismic data application and interpretation; Western Desert, Egypt. MSc thesis, Faculty of science, Ain Shams University, Egypt, pp 48-49

Iheanacho PC (2014), Formation-resistivity theory: how Archie equations, shaly reservoir models, conductive rock-matrix model, and dual-triple-porosity models are related. In: 2013 Nigeria annual international conference and exhibition, SPE 167507

Juhasz I (1981) Normalized $Q_{v}$ - the key to shaly sand evaluation using the Waxman-Smits equation in the absence of core data. In: SPWLA, 22nd, annual logging symposium

Mahsoub M, Abulnasr R, Boukhary M, Faris M, Abd El Aal M (2012) Bio-and sequence stratigraphy of Upper Cretaceous-Palaeogene rocks, East Bahariya Concession, Western Desert, Egypt. Geol Croat 65(2):109-138

Meshref W (1990) Tectonic framework. In: Said R (ed) The geology of Egypt. A.A. Balkema, Rotterdam, pp 113-155

Moustafa AR, Khalil MH (1990) Structural characteristics and tectonic evolution of north Sinai fold belts. In: Said R (ed) The geology of Egypt. A.A. Balkema, Rotterdam, Brookfield, pp 381-389

Murphy RP, Owens WW (1972) A new approach for low resistivity sand $\log$ analysis. J Pet Technol 24(11):1302-1306

Poupon A, Leveaux J (1971) Evaluation of water saturation in shaly formation. In: SPWLA 12th logging symposium

Said R (1962) The geology of Egypt. American Elsevier Pub. Co., New York, p 377

Said R (1990) The geology of Egypt. AA Balkema Publishers, Rotterdam

Schlumberger (1972) Log interpretation manual/principles, volume I. Schlumberger Well Services, Houston

Schlumberger (1989) Log interpretation principles and applications. Schlumberger Well Services, Houston

Schlumberger (1995) Schlumberger Well Evaluation Conference, Egypt
Schlumberger Technology Forum (2010) Borehole imaging evolution, measurement principles, processing and interpretation

Schön JH (2011) Physical properties of rocks: a workbook. In: Handbook of petroleum exploration and production, vol 8. Elsevier, Netherlands, pp 32-43

Shedid SA, Saad MA (2017) Comparison and sensitivity analysis of water saturation models in shaly sandstone reservoirs using well logging data. J Pet Sci Eng 156:536-545

Shokry IM, Abu Elyazid AK, Clerk C, ElAnbaawy MI (2015) Integrated petrophysical approach on reservoir characterization of shaley-sand thin bedded formation. A case study of Upper Bahariya Formation in Missaada Field, Abu Gharadig basin, Egypt. SPE-175822-MS

Simandoux P (1963) Dielectric measurements on porous media: Application to measurement of water saturation. In: Shaly sand reprint volume. SPWLA, Houston, pp 4, 97-124

Thomas EC, Stieber SJ (1975) The distribution of shale in sandstones and its effect upon porosity. In: SPWLA sixteenth annual logging symposium, June 4-7

Tixier MP, Morris RL, Connell JG (1968) Log evaluation of low resistivity pay sands in the Gulf Coast. Log Anal 9:3-20

Wahdan M, Fahmy M, Brekelmans H (1996) 3D reservoir modelling and simulation in BAPETCO: case studies from the BED 1, 2 and 3 fields, Western Desert, Egypt. In: Proceedings 13th petroleum conference, EGPC, Cairo, Production 2, pp 250-260

Waxman MH, Smits LJ (1968) Electrical conductivities in oil bearing Shaly Sands. SPE J Pet Technol Trans AIME 243:107-122

Waxman MH, Thomas EC (1974) Electrical conductivities in oil-bearing Shaly sands: I. The relation between hydrocarbon saturation and resistivity index. II. The temperature coefficient of electrical conductivity. Soc Pet Eng J 14:213-225

Wehr F, Plahn S, Bakr A, El Mansoury T, Sedky N, Youle J, Pemberton $G$ (2002) Integrated reservoir characterization studies in the Khalda Concession, Western Desert, Egypt. AAPG Poster 2002

Wyllie MRJ, Rose WD (1950) Some theoretical considerations related to the quantitative evaluation of the physical characteristics of reservoir rock from electrical log data. International. Perforation Forum. Technology. Paper No. 189

Publisher's Note Springer Nature remains neutral with regard to jurisdictional claims in published maps and institutional affiliations. 